\title{
Quality deterioration of wet fish caught in Mymensingh farm in different steps of distribution channel towards Dhaka
}

\author{
M. M. Hossain, M. N. Hassan, U. J. Lithi and A. A. K. M. Nowsad \\ Department of Fisheries Technology, Bangladesh Agricultural University, Mymensingh-2202, Bangladesh, Email: \\ motalebufo@yahoo.com
}

\begin{abstract}
The fish landed for domestic consumption suffers from serious post harvest loss due to ignorance and negligence of the people involved in the harvest, distribution, processing and trade. Low quality fish is a constraint for food security and public health and is a cause for economic loss. The present study was carried out to identify the cause and to quantify the post harvest loss by a sensory tool. Quality deterioration of some major inland species of wet fish was determined at different steps of distribution channel from the fish farm gate of Mymensingh to Dhaka retail markets in June and July 2010. Five distribution channels i.e. farm gate, transport, arot (commission agent), wholesale and retail markets were studied to find out the deterioration level of the quality of fish. Data were collected by travelling with fish and from the stakeholders in distribution channel through questionnaire interviews. In the distribution channel of wet fish RRA and SWOT analysis were done with fish farmer, arotder, transporter, wholesaler and retailer. The major species studied were Indian major carps (Labeo rohita, Catla catla and Cirrhina mrigala), pangas (Pagasius sutchi), silver carp (Hypopthalmichthys molitrix) and tilapia (Oriochromis niloticus). Different species showed different levels of deterioration of quality at various steps of distribution channels. The quality of fish was found to be changed in between arot and retail market. Inadequate knowledge and practice in handling, icing and container use were found to be the major bottlenecks to keep the fish in acceptable quality.
\end{abstract}

Keywords: Post-harvest loss, Defect point, Distribution channel, Quality loss

\section{Introduction}

Bangladesh has immense potential in fisheries resources. The extent of water areas is about 4.9 million hectares which is about $34 \%$ of total land area of the country. The water resources of the country are much diversified. A huge number of ponds, dighis, ditches, canals, rivers, haors and baors are lying in the country. There are about 13 lac ponds covering the area of 3.05 lac hectares and 24000 kilometers rivers covering the area of 10.32 lac hectares in the country. On the other hand 11000 of beels of 54488 hectares,1.14 lac hectares of baors, kaptai lake of 68000 hectares and a huge floodplain of 28.30 lac hectares categorized the diversification of water bodies of the country. About 13 million people of the country directly or indirectly involved in fisheries and about 13 lac fishermen took fishing as their unique occupation. Fisheries sector contributes about $4.07 \%$ to the national GDP of the country. The total production of fish was 30.61 lac metric tons in 2010-2011 where the production of inland water and marine water were 25.15 lac metric tons and 5.46 lac metric tons respectively (DOF, 2012. From time immemorial, fish is being used as the prime item with rice in Bangladeshi dishes. Before 1970, fish were only harvested from the natural water bodies. A few numbers of ponds or ditches were used for fish culture. The people could easily get fish from natural water bodies. Then the technology was also not widespread to produce fish. With the increase of population, fish production from natural water bodies decreased and the production from inland water through culture increased rapidly. In the recent past, fishing was confined to the lower cast of Hindus and to very few of Muslims. But with the demand of fish, people of all classes are engaged in fish culture and now fish culture has become very profitable business compared to other business.

In Bangladesh, fish marketing and distribution varies from area to area. Both the marketing and distribution of fish are most under the private sector. About $97 \%$ of the total production of fish is marketed internally for domestic consumption while the remaining $3 \%$ is exported (DOF,2010). The marketing system in Bangladesh is traditional, complex and less competitive, but plays a vital role in connecting the fish producers and consumers. High temperature in tropical climate spoils fish while still in the boat, at landing, during storage or processing, on the way to the market and even while waiting to be sold (FAO, 2003). Minimizing post-harvest losses is one of the keys to increasing revenues and food security, without 
intensifying the fishing effort (FAO, 2003). A great deal of efforts have been made by the DFID and Natural Resources Institute of UK on post-harvest loss reduction in collaboration with many African and Asian countries that include fish loss assessment and control pack, system based approach of loss reduction, etc. (DFID, 2002). In Africa some estimates put post-harvest losses at 20-25\% and sometimes as much as 50\% (Focus, 2003). Post-harvest fish losses have been studied in detail in India and effective loss reduction tools were developed (Ward, 2000). The quantity of fish whatever landed for consumption suffers from serious post harvest loss due to ignorance and /or negligence of the people involved in the harvest, distribution, processing and trade (Nowsad, 2004). The improper handling and processing reduces the quality as well. Such low quality fish is a great concern for food security and public health. It also results in serious economic loss for the processors and fish traders. Furthermore, the poor in the post-harvest fisheries sector are the most likely to suffer from the negative consequences of change, primarily because the policies that influence how change affects the poor are not always informed by an adequate knowledge of the strengths, capacities and needs of the poor. A study showed that about $20 \%$ marine fish was deteriorated $50-70 \%$ of its original quality before it reached local retail shop and about $30 \%$ fish lost $70 \%$ of its quality during distant transport (Nowsad, 2004). There is no standard handling facility that can ensure its quality. Rather chance of contamination by spoilage bacteria is very high, quality deterioration is enormous, keeping quality and nutritional status is very poor. The quality loss of fish is not understood at least up to $50 \%$ of deterioration by organoleptic means (Sakaguchi, 1990), consumers usually take it without any complain on quality. For many fish species, glut catches occur, and then the distribution and marketing system may be unable to cope with the quantities of fish which are landed. In other places the processing facilities such as drying racks may be inadequate. Then much of the fish has to be left to rot. This study was carried out to investigate the post-harvest losses of C. catla, L. rohita, C. mrigala, P. sutchi, $H$. molitrix and O. niloticus in different stages of their distribution and marketing from Mymensingh to Dhaka for getting information on quality deterioration and existing handling and icing conditions so that suggestions for improving such practices can be made.

\section{Materials and Methods}

\section{Study period}

The study was carried out for the period of nine months from June 2010 to July 2010 for getting a detailed information about the quality deterioration during distribution of fish.

\section{Study area}

To carry out the present study, fish distribution channels were selected from Mymensingh to Dhaka. Three farms of Shambuganj, Mymensingh were selected.

Stakeholder selection: In the distribution channel and marketing system of wet fish four important stakeholders were selected. The stake holders were i) fish farmer ii) transporter iii) aratder and v) retailer.

\section{Species of fish}

The species studied were Indian major carps (L. rohita, C. catla and C. mrigala), pangas ( $P$. sutchi), silver carp (H. molitrix) and tilapia (O. niloticus)

Catching of fish: Harvesting of fish was done by the fish owners. Fish were caught from the pond by seine net at night. Then the fish were sorted species wise and marketable fish were selected for sale. All fish were weighed and the carps were taken in the container.

Transportation of fish: Fish were transported in open truck from the farm gate to whole sale market. Fish were taken in the plastic container with water and in the bamboo made basket in case of live pangas and carps respectively immediately after catch. Water used in the container was taken from deep tube well and from the pond too. From the whole sale market, fish were taken in aluminium pot for sale in the retail market. Fish were transported at night and it took about eight hours from farm gate to retail market. 


\section{Auctioning of fish}

Fish were auctioned in two wholesale markets i) in Jatrabari wholesale market and ii) in Rampura bazar wholesale market. Wholesale markets were chosen mainly on the basis of high market price, prompt sale, and easy communication. Auctions were stared at 6 am and continued up to 9 am. Retailers usually are gathered in the whole sale market and took part in auction. The buyers who offer highest price in the auction took the fish from the wholesaler. Sometimes fish are sold by weighing. In that case the retailers could buy fish as their wish.

Retail markets: Fakirapool retail fish market and Segunbagicha fish market were selected for the study. Retail markets were selected on the basis of distance. The small but crowded markets were selected. Usually fish are sold on plastic tray in the retail market. But live fish are kept in the earthen or plastic pot in water and sold in live condition. The retailers try to keep the quality good by using ice and frequent use of water on the fish. Unsold fish are kept in ice box or with ice in bamboo basket for later sale.

\section{Assessment of sensory quality loss in wet fish}

Quality loss of wet fish in different stages of distribution channel was assessed according to the modified method of Nowsad (2010). The method was based on Fish Loss Assessment and Control Tool originally developed by Torry Research Institute, U.K (Sakaguchi, 1990). At first sensory defect points (DPs) of the fishes at different steps of distribution channels were determined using Table 1 and the quality of fish was determined according to Table 2 .

Table 1. Defect points (DP) for assessment of quality loss of fish

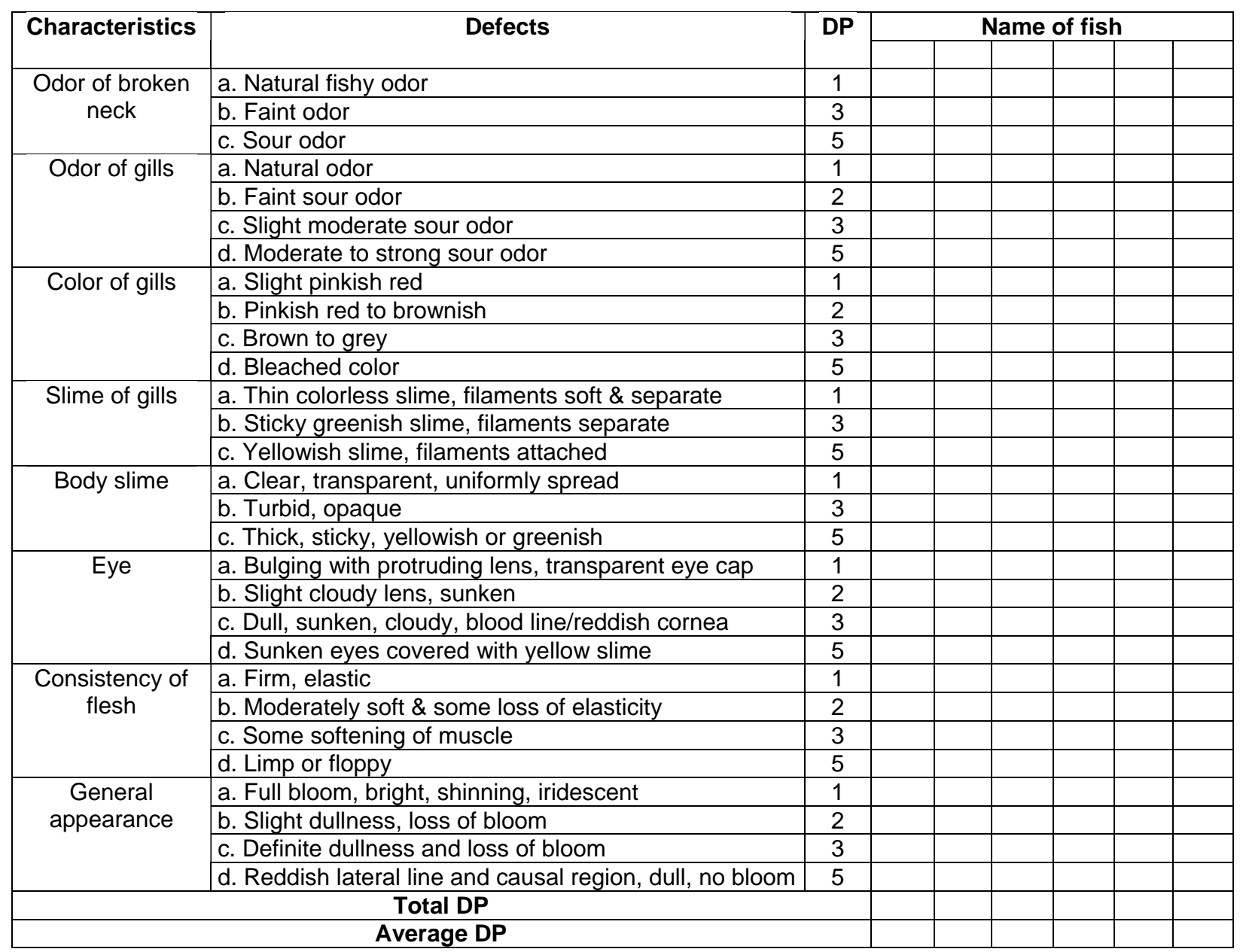

*1 Indicators modified based on Howgate et al. (1992) and Connell (1990) 
Table 2. Quality grade of fish with Defect Points (DP)

\begin{tabular}{|c|c|c|}
\hline Grade & DP & Grade Characteristics \\
\hline A & $<2$ & Excellent, highly acceptable \\
\hline B & 2 to 3 & Good, acceptable \\
\hline C & $>3$ to $<4$ & Deteriorating, not acceptable \\
\hline D & 4 to 5 & Spoilt, rejected \\
\hline
\end{tabular}

*2 Howgate et al. 1992

Percent loss of fish in each step of distribution was calculated according to Nowsad (2010). After death fish undergoes biochemical and microbiological changes and these changes are accelerated with the laps of time. Each chemical and microbiological quality parameters has a quality cut-off point beyond which the fish is said to be deteriorated or not acceptable. In a separate study the quality cut-off points of some key chemical and microbiological quality parameters of fish were determined (Nowsad, 2010). When plotted in a graph, the quality cut-off points of those chemical and microbiological parameters intercepted the sensory DP of 3.3 at x- axis, determining that the DP 3.3 was the quality breaking point of the fishes in existing handling conditions (Nowsad, 2010). Quality loss (\%) was calculated from the number of assessed cases that crossed DP 3.3 in different investigations. The following formula (Nowsad, 2010) was used to calculate percent quality loss of fish.

$L \%=\frac{P_{\mathrm{i}}}{\mathrm{N}} \times 100$

$\mathrm{L} \quad=$ Percent quality loss

$\mathrm{N}=$ Number of observed lots

$\mathrm{Pi}=$ Total number of calculated DP those crossed DP 3.3

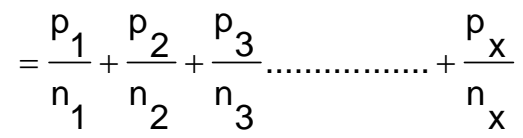

Where ' $p$ ' is the number of DP crossed 3.3 in fishes in ' $x$ ' number of lots and ' $n$ ' is the number of observations in each lot.

Each of the 2 fish farms sold and transported their fish to Dhaka on regular basis. For each of the farms, two research voyages were made, one in June and another in July. Thus 4 research voyages were made. In each voyage, the data collectors moved along with the fish from the origin of harvest through the distribution channels up to retailers and assessed the quality deterioration of same fish or same lot of fish. In every step of distribution, at least five lots of same fish and 5 individual measurements for each lot were assessed based on Table 1. Thus the quality deteriorations of the same fish or same lot of fish were assessed during its movement from harvest to retailers.

\section{Results and Discussion}

The quality defect points of the assessed fishes in the distribution channel from Mymensingh to Dhaka have been presented in Table 3. A total of 2 voyages were made where the same fish or the same lot of fish were evaluated through its movement from farms to retail fish shops. The average of the quality data are presented. The quality of fish was degraded with the time passed. In C. catla, the defect point (DP) was 1.0 at farm gate (Shambuganj, Mymensingh) at $8.00 \mathrm{pm}$, but $3.01 \pm 0.89$ at retail markets at $5.00 \mathrm{pm}$ of the following day. The scenario was almost similar in case of other 5 species. The DP started with 1.0 but ended with $3.04 \pm 1.42,3.13 \pm 1.32,2.50 \pm 1.13,3.10 \pm 1.10,3.04 \pm 0.54$ in L. rohita, C. mrigala, P. sutchi, H. molitrix and O. niloticus, respectively. Table 2 showed that the fish having DP in the range between 3 and 4 were deteriorating and not acceptable. In other study, Nowsad (2010) determined the sensory quality breaking point of fish at DP 3.3. The quality loss levels are often said to be between 20 and $40 \%$ in 
some fisheries (Cheke and Ward 1998). Some estimates of loss are probably no more than visual ones which, although valuable, can be misleadingly inaccurate (Wood and Walker, 1987). Based on the results, it was observed that most of the fishes lost their quality acceptance level at the retail fish shops. The fishes those were well taken care off during transportation were found in good quality. Temperature gradually increased as the sunshine became intense. Obviously, the rate of deterioration was accelerated by the higher ambient temperature that resulted higher oxidation. Mansur et al. (2002) also found similar results. The initial temperature was $33.0^{\circ} \mathrm{C}$ at $8.00 \mathrm{pm}$ and reached to $34.0^{\circ} \mathrm{C}$ at $5.00 \mathrm{pm}$ of the day. Initial ice to fish ratio during the start of distribution path was 1:3. Re-icing was not done during transportation or auctioning. Ice was found to be completely melted down by the time the fish reached auction center in Dhaka. After auction, a very little amount of ice was used by the retailers. During retail sale, however, re-icing and sprinkling of cold water over fish were done.

Table 3. Sensory defect point (DP), ambient temperature and handling situation, time spent for fish trip at different distribution channels

\begin{tabular}{|c|c|c|c|c|c|c|c|c|c|}
\hline \multirow{2}{*}{$\begin{array}{l}\text { Distribution } \\
\text { steps }\end{array}$} & \multicolumn{6}{|c|}{ Sensory defect point (DP) of fish } & \multirow{2}{*}{$\begin{array}{c}\text { Temperature } \\
\left({ }^{0} \mathrm{C}\right)\end{array}$} & \multirow{2}{*}{$\begin{array}{l}\text { Handling } \\
\text { situation }\end{array}$} & \multirow[t]{2}{*}{ Time } \\
\hline & C. catla & L. rohita & C. mrigala & P. sutchi & H. molitrix & O. niloticus & & & \\
\hline $\mathrm{IaC}$ & $1.00 \pm 0$ & $1.0 \pm 0.00$ & $1.00 \pm 0.00$ & $1.0 \pm 00$ & $1.00 \pm 00$ & $1.00 \pm 00$ & 33.0 & & $8.00 \mathrm{pm}$ \\
\hline LoT & $1.10 \pm 0.12$ & $1.11 \pm 0.10$ & $1.12 \pm 0.15$ & $1.0 \pm 00$ & $1.05 \pm .77$ & $1.11 \pm 0.19$ & 33.0 & $\begin{array}{l}\text { Inadequate icing } \\
\text { and washing }\end{array}$ & $9.00 \mathrm{pm}$ \\
\hline MwT & $1.23 \pm 0.23$ & $1.18 \pm 0.65$ & $1.23 \pm 0.14$ & $1.18 \pm 0.13$ & $1.23 \pm 0.82$ & $1.18 \pm 0 . .70$ & 33.0 & No re-icing & $9.30 \mathrm{pm}$ \\
\hline WM-1 & $1.83 \pm 1.12$ & $2.03 \pm 0.18$ & $2.18 \pm 0.61$ & $2.0 \pm 0.05$ & $2.31 \pm 0.05$ & $2.00 \pm 0.06$ & 33.5 & No re-icing & $6.00 \mathrm{am}$ \\
\hline WM-2 & $2.10 \pm 1.02$ & $2.10 \pm 0.72$ & $2.44 \pm 0.46$ & $2.10 \pm 1.28$ & $2.56 \pm 0.86$ & $2.05 \pm 0.66$ & 33.5 & No re-icing & $6.00 \mathrm{am}$ \\
\hline RM-1 & $2.60 \pm 0.86$ & $2.64 \pm 1.05$ & $2.53 \pm 0.78$ & $2.25 \pm 1.80$ & $2.60 \pm 1.84$ & $2.20 \pm 1.74$ & 34.0 & $\begin{array}{l}\text { Little icing or no } \\
\text { icing }\end{array}$ & $2.00 \mathrm{pm}$ \\
\hline $\mathrm{RM}-2$ & $3.01 \pm 0.89$ & $3.04 \pm 1.42$ & $3.13 \pm 1.32$ & $2.50 \pm 1.13$ & $3.10 \pm 1.10$ & $3.04 \pm 0.54$ & 34.0 & Little icing & $5.00 \mathrm{pm}$ \\
\hline
\end{tabular}

$\mathrm{laC}=$ Immediately after catch; LoT= Loaded on truck; MwT= Mid-way transportation; $\mathrm{WM}=$ Wholesale market; RM= Retail market

Mainly bamboo baskets wrapped in by polythene sheet and recently invented metallic box were used to transport the fish. During packing, bamboo baskets of 30-40 kg capacity were raised by bamboo sticks and polythene sheet to about 1.5 to 2.0 feet so that the capacity of basket increased up to $180-200 \mathrm{~kg}$ fish. There was no opening to drain out the melted water. Open truck were used to carry fish. Baskets filled with $180-200 \mathrm{~kg}$ fish were kept on the truck side by side. Retailer collected the fish from wholesale market with little or no ice since most of the ice was found to be melted down. The retailers carried their fish by aluminium tray. Most cases retailers did not use sufficient ice to keep the fish fresh. As a result with the passing of time and increase of temperature fishes were deteriorated in different extent (Table 5).

Table 4. Container used and other conditions applied during transportation of fish

\begin{tabular}{|c|c|c|c|c|c|}
\hline \multirow[t]{2}{*}{ Fish } & \multicolumn{5}{|c|}{ Container and conditions } \\
\hline & Farm gate & Packing & Transportation & Wholesaler & Retailer \\
\hline C. catla & $\begin{array}{c}\text { Bamboo basket/ plastic } \\
\text { drum/metallic box, } \\
\text { no insulation }\end{array}$ & $\begin{array}{c}\text { Raised bamboo basket } \\
\text { with polythene sheet and } \\
\text { bamboo stick }\end{array}$ & Open truck & $\begin{array}{l}\text { Open on } \\
\text { metallic tray }\end{array}$ & Aluminium tray \\
\hline L. rohita & $\begin{array}{c}\text { Bamboo basket; no } \\
\text { insulation }\end{array}$ & $\begin{array}{l}\text { Raised bamboo basket } \\
\text { with polythene sheet, }\end{array}$ & Open truck & $\begin{array}{c}\text { Open on } \\
\text { metallic tray }\end{array}$ & Aluminium tray \\
\hline C. mrigala & $\begin{array}{l}\text { Bamboo basket; } \\
\text { no insulation }\end{array}$ & $\begin{array}{l}\text { Bamboo basket with } \\
\text { polythene sheet }\end{array}$ & Open truck & $\begin{array}{c}\text { Open on } \\
\text { metallic tray }\end{array}$ & Aluminium tray \\
\hline P.sutchi & Plastic drum & Plastic drum & Plastic drum & Plastic drum & $\begin{array}{l}\text { Plastic drum and } \\
\text { aluminium tray }\end{array}$ \\
\hline H. molitrix & $\begin{array}{l}\text { Bamboo basket; } \\
\text { no insulation }\end{array}$ & $\begin{array}{l}\text { Bamboo basket with } \\
\text { polythene sheet }\end{array}$ & $\begin{array}{c}\text { Placed on open } \\
\text { truck side by } \\
\text { side }\end{array}$ & $\begin{array}{l}\text { Open on } \\
\text { metallic tray }\end{array}$ & Aluminium tray \\
\hline O. niloticus & $\begin{array}{l}\text { Bamboo basket; } \\
\text { no insulation }\end{array}$ & $\begin{array}{l}\text { Bamboo basket with } \\
\text { polythene sheet }\end{array}$ & Open truck & $\begin{array}{c}\text { Open on } \\
\text { metallic tray }\end{array}$ & Aluminium tray \\
\hline
\end{tabular}


The percent quality loss of fish was determined in different stages of distribution channel (Table 5). In determining the quality loss, quality of fish at all steps in all 2 voyages were considered and average was taken. Neither of the fish lost their quality when they were in the farm gate, during packing and transportation and in wholesale markets. The quality loss was $4.4 \% \pm 0.10,5.0 \% \pm 0.3,5.5 \% \pm 1.2$, $2.3 \% \pm 0.2,5.2 \% \pm 0.11$ and $3.1 \% \pm 0.1$ in case of $C$. catla, , L. rohita, C. mrigala, P. sutchi $H$. molitrix and $O$. niloticus respectively in the retail markets. At the farm gate, fishes were fresh and freshness in terms of average DP were in acceptable range (DP >3.3) during transportation up to the wholesalers. It was observed that, $C$. mrigala encountered highest loss $(5.5 \% \pm 1.2)$, followed by $H$. molitrix $(5.2 \% \pm 0.11)$ and $L$. rohita $(5.0 \% \pm 0.30)$. The losses might be associated with landing conditions, size and oil contents encountered with high ambient temperature. Within the same lot deterioration of grass carp and mrigal might be due to their less firmness of the muscle compared to other species. However the percent loss of the studied fishes transported from Mymensingh to Dhaka were slightly lower than the percent quality loss of fish (12\%-16\%) determined from many different distribution channels of the entire country (Nowsad 2010). Nowsad (2010) estimated the post harvest quality loss of 28 commercial freshwater and marine fishes under different seasonal and handling conditions and in different short to long distribution channels in Bangladesh. The average post harvest loss in retailers for C. catla, L. rohita, C. mrigala, C. idellas and $H$. Molitrix were found to be $12 \%, 16 \%, 11 \%, 12 \%$, and $13 \%$ respectively Nowsad (2010). Due to difference in handling conditions, post harvest loss was observed not only in retailers or vendors but also in wholesalers and transporters. C. catla, L. rohita, C. mrigala, C. idellas and H. Molitrix were found to be lost by $3 \%, 4 \%, 6 \%, 3 \%$, and $3 \%$ respectively in transporters (Nowsad 2010). In that study fish landed from both capture and culture fisheries were studied and average value of all types of fishes in all distribution channels were taken. But, in our present study, farm-raised fishes were transported immediately after harvest through definite distribution route without lapsing time. The present distribution route was more or less smooth and comparatively better care was taken during transportation up to wholesalers of Dhaka.

Table 5. extent of quality loss of fish (\%) in different stages of distribution channel

\begin{tabular}{|l|l|c|c|c|c|c|c|}
\hline \multicolumn{1}{|c|}{ Fish } & \multirow{2}{*}{$\begin{array}{c}\text { Month of } \\
\text { observation }\end{array}$} & $\begin{array}{c}\text { Distance of } \\
\text { consumer market } \\
(\mathrm{km})\end{array}$ & & \multicolumn{5}{|c|}{ \% quality loss } \\
\cline { 5 - 7 } & & & Farm gate & Packing & Transportation & Wholesaler & Retailer \\
\hline C. catla & June and July & 130 & - & - & - & - & $4.4 \pm 0.10$ \\
\hline L. rohita & June and July & 130 & - & - & - & - & $5.0 \pm 0.3$ \\
\hline C. mrigala & June and July & 130 & - & - & - & - & $5.5 \pm 1.2$ \\
\hline P. sutchi & June and July & 130 & - & - & - & - & $2.3 \pm 0.2$ \\
\hline H. molitrix & June and July & 130 & - & - & - & - & $5.2 \pm 0.11$ \\
\hline O. niloticus & June and July & 130 & - & - & - & - & $3.1 \pm 0.1$ \\
\hline
\end{tabular}

Some authors also observed post-harvest fish losses at different stages of distribution chain from capture to consumption in the country. Huge loss of fish due to very poor or no preservation facilities in Mymensingh area was identified by Hossain et al. (2002). Hossain and Afroze (1991) and Hossain et al. (2002) observed that for inadequate handling and preservation (icing, chilling, and freezing) or storage facilities for farmed Indian major carps, the retail fish traders suffered huge economic loss in terms of low price offered for quality deterioration. Hossain et al. $(2002,2005)$ and Hoq and Kohinoor (2005) identified the livelihoods of such fish traders as highly vulnerable in Kewatkhali and Shutiakhali Union of Mymensingh sadar. However, the losses of farmed fishes to consumer market could be minimized by adopting good handling practices like using insulated container and adequate icing during retailing. If a successful post-harvest loss reduction tools with policy supports could be developed, an estimated 50$60 \%$ of the total loss could be avoided.

\section{References}

Cheke, R.A, and Ward, A.R. 1998. A model for evaluating interventions designed to reduce post-harvest fish losses. Fisheries Research 35: 219-227.

Connell, J.J. 1990. Control of Fish Quality. 3rd Edition. Fishing News Books. Oxford. 245 pp. 


\section{Hossain et al.}

DFID (Department of International Development). 2002. Post-Fish News. Post-harvest Fisheries Research Programme News Letter. UK. Web site: http://www.phfp.uk.com.

DOF (Department of Fisheries). 2010. Brief on department of fisheries Bangladesh. DOF (Department of Fisheries). Ministry of Fisheries and Livestoc, Dhaka, Bangladesh.

DOF (Department of Fisheries). 2012. National Fish Fortnight 2012.(7-13 July, 2012) DOF (Department of Fisheries). Ministry of Fisheries and Livestoc, Dhaka, Bangladesh.

FAO. 2003. web site: http://www.fao.org/focus/e/fisheries/proc.htm.

Focus, 2003. Post-harvest losses in artisanal fisheries. Fisheries and Food Security. Food and Agriculture Organizations of the United Nations. Rome.

Hoq, M.E. and Kohinoor, A.H.M. 2005. Impact of small indeginous species of fish (SIS) on livelihood of local fishing community in two upazilas of Mymensingh. Bangladesh J. Fish Res., 9(1): 101-102.

Hossain, M.A. and Afroze, S. 1991. Small fish as a resource in rural Bangladesh. Fishbyte, 9(2): 6-18.

Hossain, M.A.R., Ali, M.Z., Khanam, M.N.A., Debnath, S. and Amin, A.K.M.R. 2002. Participatory rural appraisal with small indigenous species of fish (SIS) retailers in two fish markets. Progress. Agric. 13 (1 \& 2): 133-138.

Hossain. M.A.R., Chowdhury, N.S. and Ali, M.Z. 2005. Marketing of small indigenous species of fish (SIS) in three selected fish markets of Mymensingh. Bangladesh J. Fish.Res., 9(1): 91-93.

Howgate, P.A., Johnston, K. and Whittle, J. 1992. Multilingual Guide to EC Freshness Grades for Fishery Products. Torry Research Station. Food Safety Directorate, Ministry of Agriculture, Fisheries and Food, Aberdeen, Scotland.

Mansur, M.A., Chakraborty, S.C., Hossain, M.I., Shikha, F.H. and Akter, F. 2002. Freshness of freshwater fish species at landing centre and in market of an urban area of Mymensingh, Bangladesh. Bangladesh journal Fish. 25(1-2): 53-59.

Nowsad, A.K.M.A. 2004. Landing Center Monitoring. Report on a survey research done in collaboration with Bangladesh Center for Advanced Studies and Center for Natural resources Studies. ECFC Field Rep. 2004. 189 pp.

Nowsad, A.K.M.A. 2010. Post-harvest Loss Reduction in Fisheries in Bangladesh: A Way Forward to Food Security. Final report $\mathrm{PR} \# 5 / 8$.

Sakaguchi, M. 1990. Ojective and subjective methods for measuring freshness of fish. Department of Fisheries, Faculty of Agriculture, Kyoto University, Sakyo-ku 606, Kyoto, Japan.

Walker, D.J. and Wood, C.D. 1987. Reduction of losses in cured fish in tropics- guide for extension workers. Report of the Tropical Development and Research Institute G 204.

Ward, A.R. 2000. Monsoon season post-harvest losses in traditional fish processing in India> Final Technical Report on Research Project R6817. Report No. 2541 Natural Resources Institute, Chatham, 48 pp. 